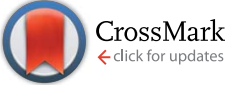

Cite this: RSC Adv., 2017, 7, 3419

Received 16th October 2016 Accepted 18th November 2016

DOI: $10.1039 / \mathrm{c} 6 \mathrm{ra} 25310 \mathrm{e}$

www.rsc.org/advances

\section{Synergistic protective effect of carboxymethyl chitosan and cathodic protection of X70 pipeline steel in seawater}

\begin{abstract}
Panpan Feng, ${ }^{\text {ab }}$ Kai Wan, ${ }^{a}$ Guowei Cai, ${ }^{a}$ Lihui Yang ${ }^{a}$ and Yantao Li ${ }^{\star a}$
This study has investigated corrosion inhibition performance on X70 pipeline steel in seawater using carboxymethyl chitosan (CMCS) and $\mathrm{Na}_{2} \mathrm{WO}_{4}$ at a cathodic protection potential of $-0.85 \mathrm{~V}$ ( $v s$. SCE). The corrosion behaviors were studied using electrochemical methods, scanning electron microscopy (SEM), energy-dispersive spectroscopy (EDS), X-ray diffraction (XRD) and Fourier transform infrared spectroscopy (FTIR). The results show that the inhibition efficiency increases when the CMCS concentration increases. Polarization curves reveal that CMCS and $\mathrm{Na}_{2} \mathrm{WO}_{4}$ exhibit a nice synergy for the corrosion inhibition of X70 pipeline steel in seawater. The inhibition mechanism behind the synergistic protective effect of $\mathrm{CMCS}$ and $\mathrm{Na}_{2} \mathrm{WO}_{4}$ is assumed to occur via both chemisorption on the steel surface through the active sites in the molecule and physisorption. When combined with cathodic protection, corrosion can be inhibited and calcareous deposits cannot form on the surface.
\end{abstract}

\section{Introduction}

Power plant recirculating cooling systems use freshwater as a cooling medium, which leads to the scarcity of freshwater. ${ }^{1}$ Seawater has been used more often in power plants constructed at the seaside in China to decrease the loss of water sources. ${ }^{2}$ For the convenience of connecting the pipeline to other equipment like condensers, secondary filter screens and butterfly valves, cooling water systems are usually used as part of the steel pipeline. ${ }^{3} \mathrm{X} 70$ pipeline steel is used in the cooling water systems of power plants in China. Corrosion issues in pipelines are particularly serious when seawater acts as the cooling medium. The application of corrosion inhibitors is one preventative method that has been reported to be helpful in cooling systems. ${ }^{4-8}$ Other organic compounds like anionic polymers, poly(acrylic acid) and polyaniline dispersions have been investigated as inhibitors for controlling scale deposition in cooling water. ${ }^{9-11}$

Chitosan has been widely used in many fields, such as medicine, biotechnology, agriculture and food science. ${ }^{12}$ Chitosan is a safe, nontoxic, biocompatible, and biodegradable natural alkaline polysaccharide derived from the deacetylation of chitin. ${ }^{13,14}$ CMCS is a type of chitosan derivative with better water solubility. Cathodic protection is a reliable, effective and economic method for the protection of pipelines. ${ }^{15}$ Both inhibitors and cathodic protection can be used to protect metal from corrosion in aqueous solutions. ${ }^{16-18}$ Inhibitors

${ }^{a}$ Institute of Oceanology, Chinese Academy of Sciences, Qingdao 266071, China. E-mail: ytli@qdio.ac.cn; Tel: +86-532-82898742

${ }^{b}$ University of Chinese Academy of Sciences, Beijing 100049, China such as thiourea and cations such as aluminium, calcium and magnesium under cathodic control in different solutions have been investigated and proved to be practical. ${ }^{19-22}$ However, the addition of cations and other inhibitors cannot solve the problem of scaling. With the application of recirculating water, a dense adherent scale will gradually form, grow and deposit on the metal surface. Scale deposits lower the thermal efficiency of heat exchangers and may also cause localized corrosion. $^{23,24}$

This study investigated the inhibition efficiency of CMCS and its synergistic effects with $\mathrm{Na}_{2} \mathrm{WO}_{4}$. The combined inhibitors and cathodic protection have been used both separately and together to protect metal in natural seawater. An attempt has been made to develop a new corrosion protection method for pipelines in seawater recirculating cooling systems.

\section{Experimental}

\subsection{Materials and solutions}

The test material used was X70 pipeline steel with a composition (wt\%) of: C (0.0450), Si (0.026), Mn (1.48), S (0.001), P (0.017), $\mathrm{Cr}(0.031), \mathrm{Ni}$ (0.16), Mo (0.23), Nb (0.033), $\mathrm{Cu}(0.21)$ and Fe balance. Specimens embedded in epoxy resin with an exposed area of $1 \mathrm{~cm}^{2}$ were polished with emery paper up to grade 800, degreased ultrasonically in ethanol, and dried under air flow at room temperature. The test solution used was filtered natural seawater obtained from Huiquan Bay in Qingdao, China. Carboxymethyl chitosan (CMCS) and $\mathrm{Na}_{2} \mathrm{WO}_{4}$ were provided by BomeiBio and BASF, respectively. The deacetylation degree of CMCS was more than $90 \%$. 


\subsection{Weight loss test}

The samples were immersed in a beaker containing $500 \mathrm{ml}$ $0.5 \mathrm{M} \mathrm{H}_{2} \mathrm{SO}_{4}$ solution without and with inhibitors at $303 \mathrm{~K}$ for $8 \mathrm{~h}$. Three samples were used for each test to measure the average weight loss. The samples were weighed before and after the tests using an analytical balance with a precision of $0.1 \mathrm{mg}$. The inhibition efficiency $\eta$ was evaluated by using the following equation:

$$
\eta(\%)=\frac{W_{0}-W_{\mathrm{i}}}{W_{0}} \times 100 \%
$$

where $W_{0}$ and $W_{\mathrm{i}}$ are the values for the weight loss of the X70 pipeline steel without and with the addition of inhibitors in the solution, respectively.

\subsection{Electrochemical measurements}

Electrochemical measurements were conducted using a PARSTAT 2273 advanced electrochemical system (Princeton Applied Research) at $303 \mathrm{~K}$ in test solution. A conventional threeelectrode system was used. The working electrode was X70 pipeline steel with an exposed area of $1 \mathrm{~cm}^{2}$. A platinum foil electrode and a saturated calomel reference electrode (SCE) coupled with a Luggin probe were used. Before the measurements, the working electrodes were immersed in seawater containing different concentrations of CMCS and $\mathrm{Na}_{2} \mathrm{WO}_{4}$ for $2 \mathrm{~h}$ until a stable open-circuit potential (OCP) was obtained.

Electrochemical impedance spectroscopy (EIS) measurements were carried out at OCP by applying a sinusoidal potential perturbation of $10 \mathrm{mV}$ with a frequency range from $100 \mathrm{kHz}$ to $10 \mathrm{mHz}$. The EIS data were analyzed using Zsimpwin software and fitted to the appropriate equivalent circuits. Polarization measurements were carried out from -250 to $250 \mathrm{mV} v s$. the OCP at a scanning rate of $0.5 \mathrm{mV} \mathrm{s}^{-1}$. Power Suite software was used for the analysis of corrosion current densities and polarization parameters. Three parallel measurements were performed under each experimental condition.

\subsection{Cathodic protection}

The cathodic protection was supported by a DJS-292B Potentiostat. A cathodic potential of $-850 \mathrm{mV}$ was applied on the three-electrode system mentioned above, and a carbon rod of $\Phi$ $6 \mathrm{~mm} \times 100 \mathrm{~mm}$ was used as the counter electrode.

\subsection{Surface analysis}

Scanning electron microscopy (SEM, JEOL-JSM-5600) and energy-dispersive X-ray spectroscopy (EDS, OXFORD INCA) were used to examine the specimen surface after immersion in solution for $120 \mathrm{~h}$. The surface films were further characterized using X-ray diffraction (XRD) and Fourier transform infrared spectroscopy (FTIR). XRD data were recorded on a Rigaku D/ max-TTR-III, with a $\mathrm{Cu}$ target operating at $40 \mathrm{kV}$, a scan range of $10-80^{\circ}$ and a scan rate of $20^{\circ} \mathrm{min}^{-1}$. FTIR spectroscopy was performed using a Bruker Vertex 70 FTIR and collected at a resolution of $2 \mathrm{~cm}^{-1}$ between $400 \mathrm{~cm}^{-1}$ and $4000 \mathrm{~cm}^{-1}$.

\section{Results and discussion}

\subsection{Weight loss test}

Values of $\eta$ obtained from the weight loss method in different solutions at $303 \mathrm{~K}$ are given in Table 1 . According to Table 1, the corrosion rates of the specimens decrease with the addition of CMCS. These data also indicate that the weight loss value of the steel in the solution containing CMCS decreases slightly, suggesting that CMCS alone has little inhibitory effect. In addition, the addition of only $0.1 \mathrm{~g} \mathrm{~L}^{-1} \mathrm{Na}_{2} \mathrm{WO}_{4}$ into the test solution also exhibits little inhibitory effect, as can be seen from Table 1 . The weight loss values decrease significantly when both CMCS and $\mathrm{Na}_{2} \mathrm{WO}_{4}$ are added into the test solution, indicating that the synergistic inhibitory effect between CMCS and $\mathrm{Na}_{2} \mathrm{WO}_{4}$ is better than that when only CMCS or $\mathrm{Na}_{2} \mathrm{WO}_{4}$ is added into the test solution separately.

\subsection{Polarization measurements}

The polarization curves of the X70 pipeline steel in seawater in the absence and presence of different inhibitors are shown in Fig. 1, and the electrochemical parameters obtained by extrapolation of the Tafel line are illustrated in Table 1. The inhibition efficiency (IE\%) is calculated using the following equation: ${ }^{25}$

Table 1 Weight-loss results and corrosion inhibition efficiency for X70 pipeline steel in seawater in the absence and presence of the investigated inhibitors at $303 \mathrm{~K}$ after $2 \mathrm{~h}$ immersion

\begin{tabular}{|c|c|c|}
\hline Inhibitor concentration & $\begin{array}{l}\text { Weight loss } \\
\left(\mathrm{g} \mathrm{m}^{-2} \mathrm{~h}^{-1}\right)\end{array}$ & $\eta(\%)$ \\
\hline Blank solution & 10.29 & - \\
\hline $0.25 \mathrm{~g} \mathrm{~L}^{-1} \mathrm{CMCS}$ & 1.32 & 80.95 \\
\hline $0.1 \mathrm{~g} \mathrm{~L}^{-1} \mathrm{Na}_{2} \mathrm{WO}_{4}$ & 1.28 & 82.83 \\
\hline $0.25 \mathrm{~g} \mathrm{~L}^{-1} \mathrm{CMCS}+0.1 \mathrm{~g} \mathrm{~L}^{-1} \mathrm{Na}_{2} \mathrm{WO}_{4}$ & 0.57 & 90.20 \\
\hline
\end{tabular}

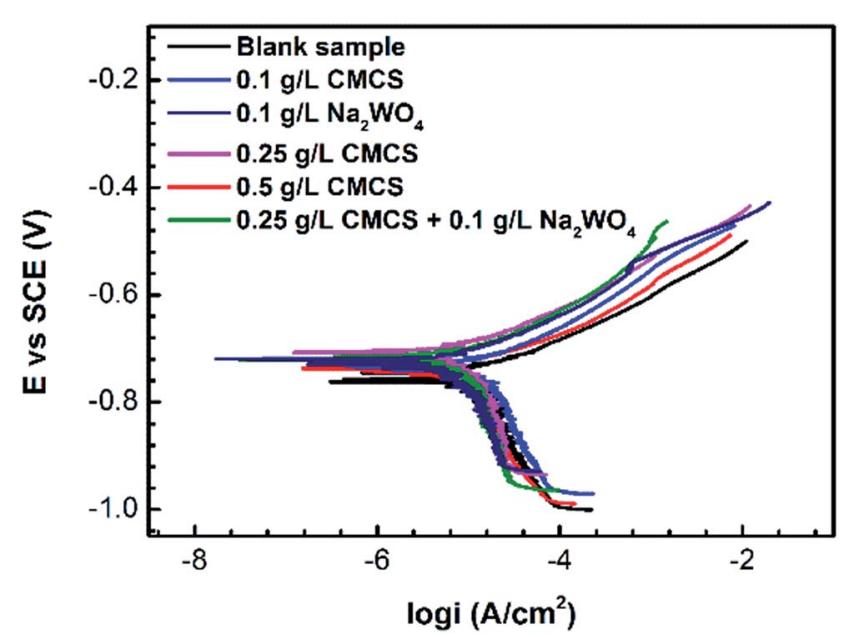

Fig. 1 Potentiodynamic polarization curves for X70 pipeline steel after $2 \mathrm{~h}$ immersion in seawater in the absence and presence of the investigated inhibitors. 


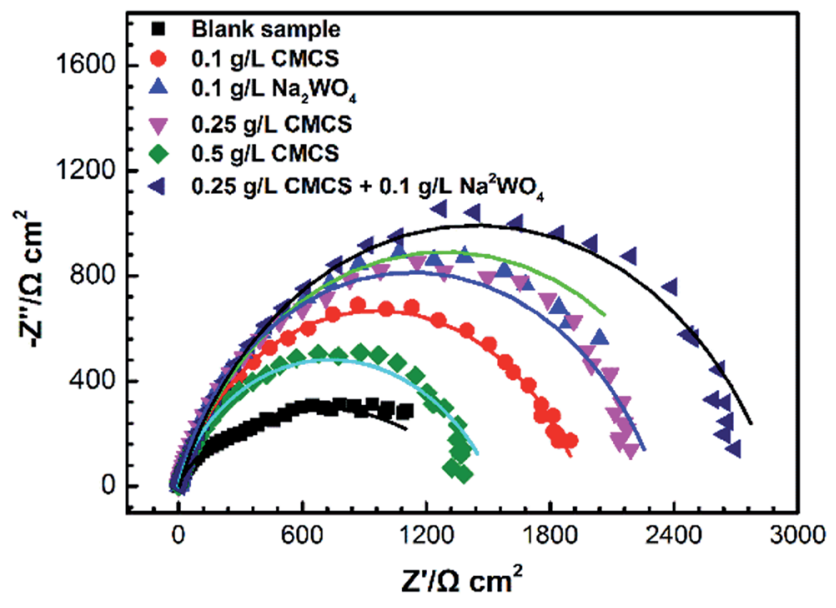

Fig. 2 Nyquist plots for $X 70$ pipeline steel after $2 \mathrm{~h}$ immersion in seawater in the absence and presence of the investigated inhibitors.

$$
\mathrm{IE} \%=\frac{i_{\text {corr }}-i_{\text {inh }}}{i_{\text {corr }}} \times 100 \%
$$

where $i_{\text {corr }}$ and $i_{\text {inh }}$ are the corrosion current densities of X70 pipeline steel in the absence and presence of inhibitors in the seawater, respectively.

The curves of the potentiodynamic polarization measurements for samples in the presence and absence of various concentrations of CMCS, $\mathrm{Na}_{2} \mathrm{WO}_{4}$ and CMCS $+\mathrm{Na}_{2} \mathrm{WO}_{4}$ in test solutions are shown in Fig. 2 . The anodic and cathodic polarization curves exhibit well-defined Tafel regions. As seen in Fig. 2, the anodic current decreases in the presence of CMCS, and then decreases again when $\mathrm{Na}_{2} \mathrm{WO}_{4}$ is added into the test solution. This shows that the addition of CMCS reduces the anodic dissolution of X70 pipeline steel and also retards the oxygen-consuming reaction. Adding only $\mathrm{Na}_{2} \mathrm{WO}_{4}$ into the test solution can also decrease the anodic current. This behavior is attributed to the adsorption of the inhibitor on the active sites of the metal surface. In addition, a better protective effect can also be seen when $\mathrm{Na}_{2} \mathrm{WO}_{4}$ is added into the test solution. Table 2 represents all the corrosion parameters, including the cathodic $\left(\beta_{\mathrm{c}}\right)$ and anodic $\left(\beta_{\mathrm{a}}\right)$ Tafel slopes, corrosion potential $\left(E_{\text {corr }}\right)$, corrosion current density $\left(i_{\text {corr }}\right)$, and percentage inhibition efficiency. The anodic curves give rise to parallel lines, indicating that the addition of CMCS to the test solution does not modify the oxygen-consuming mechanism or the reduction of oxygen at the pipeline steel surface, which occurs mainly through a charge transfer mechanism. From Table 2, it is also clear that the corrosion current density $\left(i_{\text {corr }}\right)$ decreases and the inhibition efficiency increases as the concentration of inhibitors increases. At a concentration of $0.25 \mathrm{~g} \mathrm{~L}^{-1} \mathrm{CMCS}$, the inhibition efficiency exhibits its highest value, and this increases when $\mathrm{Na}_{2} \mathrm{WO}_{4}$ is also added into the test solution. These results may be attributed to the increase in the number of active sites, electron densities and molecular size. The increase in inhibitor efficiency as the concentration increases can be interpreted on the basis of the adsorption amount, and the coverage of inhibitor molecules increases as the concentration increases. The $E_{\text {corr }}$ values shift slightly toward anodic directions, which may be due to the blocking effect of the active sites when an inhibitor is added.

\subsection{Electrochemical impedance spectroscopy measurements}

Fig. 2 shows Nyquist plots for the $\mathrm{X} 70$ pipeline steel in seawater with and without various concentrations of CMCS, $\mathrm{Na}_{2} \mathrm{WO}_{4}$ and $\mathrm{CMCS}+\mathrm{Na}_{2} \mathrm{WO}_{4}$. It is clear that the impedance response of the $\mathrm{X} 70$ pipeline steel has changed after immersion in test solution for $2 \mathrm{~h}$. We can see that the size of the semicircles increases with increasing concentration of CMCS and reaches a maximum at a concentration of $0.25 \mathrm{~g} \mathrm{~L}^{-1}$. This increases again when $\mathrm{Na}_{2} \mathrm{WO}_{4}$ is added into the test solution and the effect is better than adding CMCS or $\mathrm{Na}_{2} \mathrm{WO}_{4}$ separately. The impedance spectra of the Nyquist plots for the $\mathrm{X} 70$ pipeline steel measured in seawater were analyzed by fitting them to the equivalent circuit model shown in Fig. 3. As an example, the Nyquist and Bode plots are presented in Fig. 4. The equivalent circuit consists of a constant phase element (CPE) in parallel with the charge-transfer resistance, $R_{\mathrm{ct}}$, which is in series with the solution resistance $R_{\mathrm{s}}$. Considering that the impedance of a double layer does not behave as an ideal capacitor in the presence of dispersing effects, a CPE is used as a substitute for a capacitor to more accurately fit the impedance behavior of the electric double layer. ${ }^{26}$ The impedance parameters derived from this investigation have been obtained by fitting the Nyquist plots with the equivalent circuit and the calculated inhibition efficiencies are also mentioned in Table 3. The most widely used parameter is the CPE, which has a non-integer power dependence on the frequency. At most times, the CPE is required for modeling the frequency dispersion behavior corresponding to different physical phenomena such as

Table 2 Potentiodynamic polarization parameters for X70 pipeline steel in seawater in the absence and presence of the investigated inhibitors at $303 \mathrm{~K}$

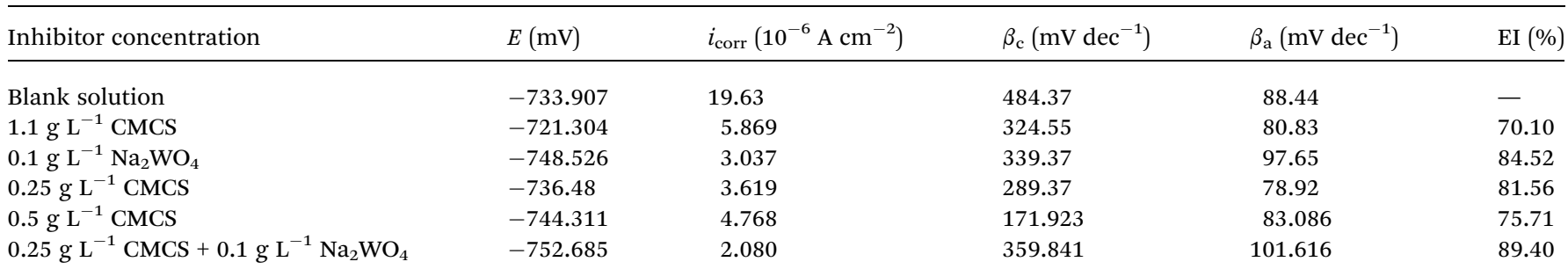




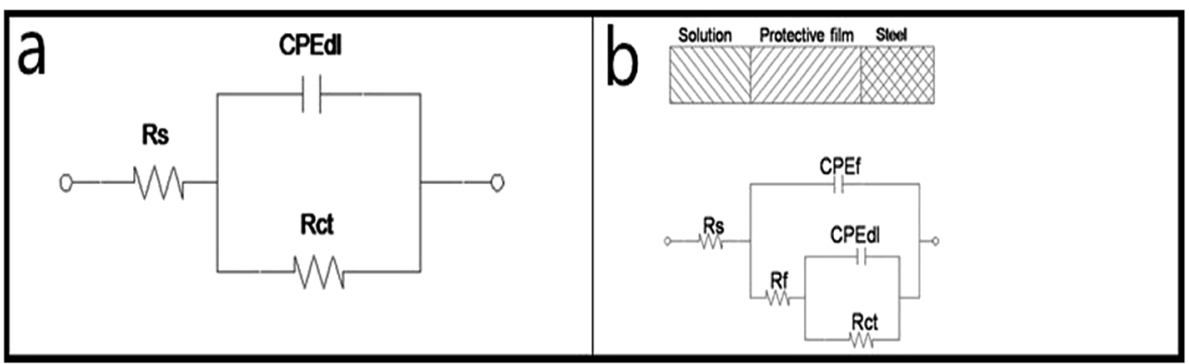

Fig. 3 Equivalent circuits used to fit EIS data after $2 \mathrm{~h}$ immersion at $303 \mathrm{~K}$ in seawater in the absence (a) and presence (b) of inhibitors.

surface heterogeneity, which results from surface roughness, impurities, dislocations, distribution of the active sites, adsorption of inhibitors and formation of porous layers. ${ }^{27}$

Table 3 shows that the charge transfer resistance increases from $997.10 \Omega \mathrm{cm}^{-2}$ in the blank solution to $5247.89 \Omega \mathrm{cm}^{-2}$ in the $0.25 \mathrm{~g} \mathrm{~L}^{-1}$ CMCS solution, and to $14244.28 \Omega \mathrm{cm}^{-2}$ upon addition of $0.1 \mathrm{~g} \mathrm{~L}^{-1} \mathrm{Na}_{2} \mathrm{WO}_{4}$. Also, the double layer capacitance decreases from $909.3 \mu \mathrm{F} \mathrm{cm}^{-2}$ in the blank solution to $568.9 \mu \mathrm{F}$ $\mathrm{cm}^{-2}$ in $0.25 \mathrm{~g} \mathrm{~L}^{-1}$ CMCS, to $214.7 \mu \mathrm{F} \mathrm{cm}^{-2}$ upon addition of $0.1 \mathrm{~g} \mathrm{~L}^{-1} \mathrm{Na}_{2} \mathrm{WO}_{4}$. The inhibition efficiency increases from $80.76 \%$ in the presence of CMCS to $92.88 \%$ upon addition of $\mathrm{Na}_{2} \mathrm{WO}_{4}$ into the CMCS solution, which agrees well with the polarization results. The enhanced inhibition efficiency noted for CMCS upon the addition of $\mathrm{WO}_{4}{ }^{2-}$ is due to a synergistic effect. The results of solely using $\mathrm{Na}_{2} \mathrm{WO}_{4}$ also verify the synergistic effect. In competitive adsorption, the anion and cations are adsorbed at different sites on the metal surface. The adsorption of anions may enhance the adsorption of cations and vice versa. In co-operative adsorption, anions are chemisorbed on the surface and cations are adsorbed on a layer of anions. Co-operative and competitive adsorption mechanisms may occur simultaneously. ${ }^{28,29}$

\subsection{Surface analysis}

Fig. 5 compares the FTIR spectra for different concentrations of CMCS. Corrosion products were obtained from samples that had been immersed in seawater with and without inhibitors. The FTIR spectrum of CMCS (Fig. 5, curve c) shows basic
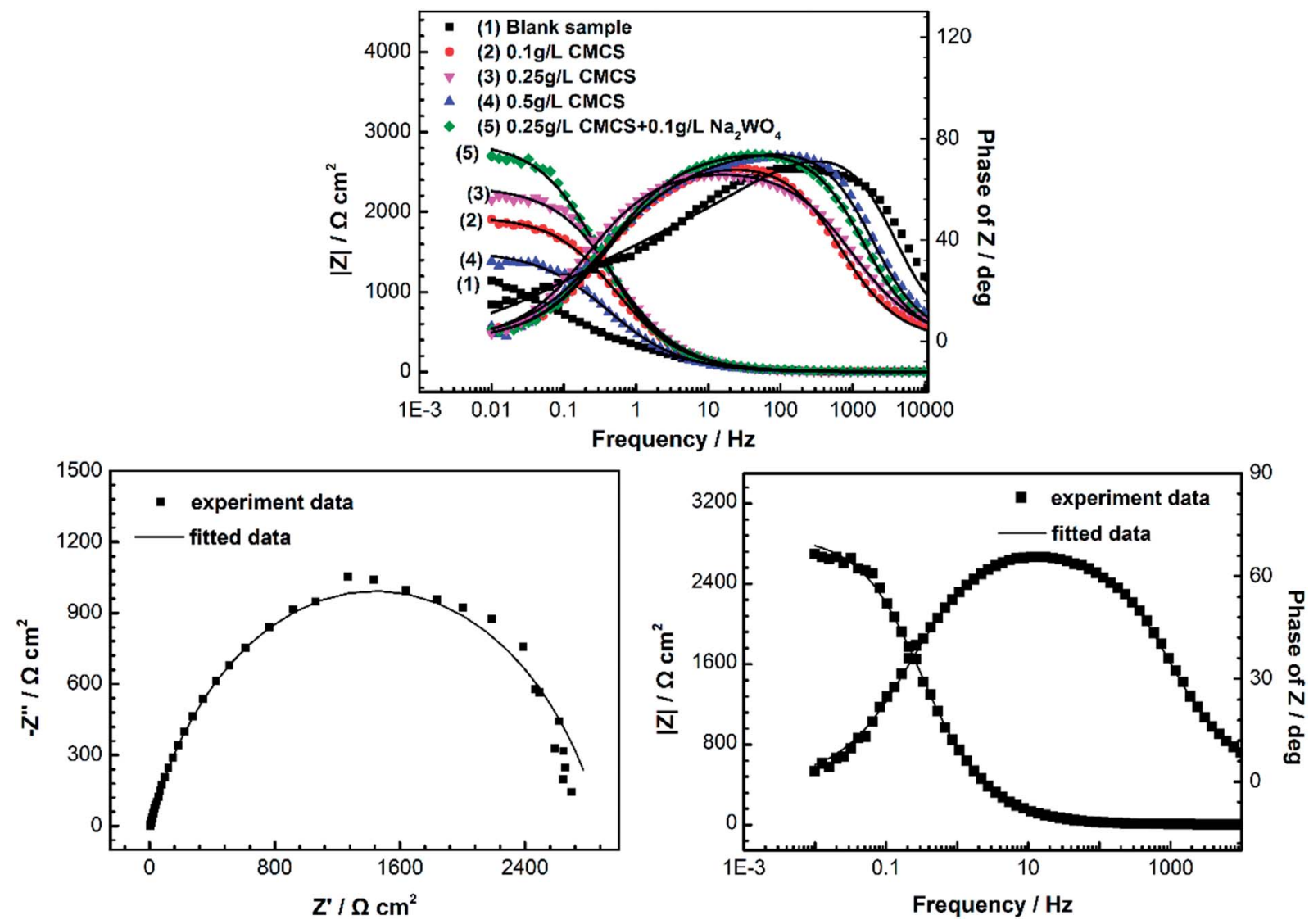

Fig. 4 EIS Nyquist and Bode plots for X70 pipe steel in seawater after $2 \mathrm{~h}$ immersion at $303 \mathrm{~K}$. Plots: experiment data, lines: fitted data. 
Table 3 EIS parameters for X70 pipeline steel after $2 \mathrm{~h}$ immersion in seawater in the absence and presence of the investigated inhibitors at $303 \mathrm{~K}$

\begin{tabular}{|c|c|c|c|c|c|}
\hline \multirow[b]{2}{*}{ Solution } & \multirow[b]{2}{*}{$\begin{array}{l}R_{\mathrm{s}} \\
\left(\Omega \mathrm{cm}^{-2}\right)\end{array}$} & \multicolumn{2}{|l|}{$\mathrm{CPE}$} & \multirow[b]{2}{*}{$\begin{array}{l}R_{\mathrm{ct}} \\
\left(\Omega \mathrm{cm}^{-2}\right)\end{array}$} & \multirow[b]{2}{*}{$\begin{array}{l}\eta \\
(\%)\end{array}$} \\
\hline & & $\begin{array}{l}C_{\mathrm{dl}} \\
\left(\mu \mathrm{F} \mathrm{cm}{ }^{-2}\right)\end{array}$ & $n$ & & \\
\hline Blank solution & 1.274 & 909.3 & 0.8712 & 997.10 & - \\
\hline $0.1 \mathrm{~g} \mathrm{~L}^{-1}$ CMCS & 1.827 & 599.3 & 0.8207 & 3561.07 & 72.21 \\
\hline $0.1 \mathrm{~g} \mathrm{~L}^{-1} \mathrm{Na}_{2} \mathrm{WO}_{4}$ & 1.635 & 587.4 & 0.8329 & 5073.21 & 80.34 \\
\hline $0.25 \mathrm{~g} \mathrm{~L}^{-1} \mathrm{CMCS}$ & 2.461 & 568.9 & 0.8602 & 5247.89 & 80.99 \\
\hline $0.5 \mathrm{~g} \mathrm{~L}^{-1} \mathrm{CMCS}$ & 1.755 & 606.1 & 0.9013 & 3835.01 & 74.47 \\
\hline $0.25 \mathrm{~g} \mathrm{~L}^{-1}$ & 1.047 & 214.7 & 0.8902 & 14244.28 & 92.88 \\
\hline \multicolumn{6}{|l|}{$\mathrm{CMCS}+0.1 \mathrm{~g} \mathrm{~L}^{-1}$} \\
\hline $\mathrm{Na}_{2} \mathrm{WO}_{4}$ & & & & & \\
\hline
\end{tabular}

characteristic adsorption bands around $3423 \mathrm{~cm}^{-1}(\mathrm{O}-\mathrm{H}$ and $\mathrm{N}-\mathrm{H}$ stretching vibrations), $1599 \mathrm{~cm}^{-1}$ corresponding to the $-\mathrm{NH}_{2}$ group, and $1070 \mathrm{~cm}^{-1}$ (skeletal vibration involving the $\mathrm{C}-\mathrm{O}$ stretch). ${ }^{14,31-33}$

These characteristic adsorption bands of CMCS appear in curve b, indicating the existence of CMCS on the carbon steel surface, while they are not observed in the FTIR spectrum of the corrosion product obtained from the sample immersed in blank seawater (Fig. 5a). This illustrates that CMCS can be adsorbed on the surface.

Fig. 6 compares the morphologies and EDS of X70 pipeline steel surfaces after 5 days of immersion at $303 \mathrm{~K}$ in seawater in the absence (Fig. 6a) and the presence of $0.25 \mathrm{~g} \mathrm{~L}^{-1}$ CMCS (Fig. 6b), $0.1 \mathrm{~g} \mathrm{~L}^{-1} \mathrm{Na}_{2} \mathrm{WO}_{4}$ (Fig. 6c) and $0.25 \mathrm{~g} \mathrm{~L}^{-1} \mathrm{CMCS}+0.1 \mathrm{~g}$ $\mathrm{L}^{-1} \mathrm{Na}_{2} \mathrm{WO}_{4}$ (Fig. 6d). The calculation of surface element content is shown in Table 4. The content of $\mathrm{Na}$ and $\mathrm{Cl}$ were measured due to the nature of the seawater. Samples were dried under cold air flow, and were not washed with distilled water. $\mathrm{Na}$ and $\mathrm{Cl}$ are not included in Table 4 .

The surface morphology of the sample in seawater in the absence of inhibitors shows a loose and porous structure. The EDS pattern in Fig. 6a shows that $\mathrm{Fe}$ and $\mathrm{O}$ were the main elements on the surface. The XRD pattern (Fig. 7a) confirms that the main product is lepidocrocite $(\mathrm{Fe}+3 \mathrm{O}(\mathrm{OH}))$.

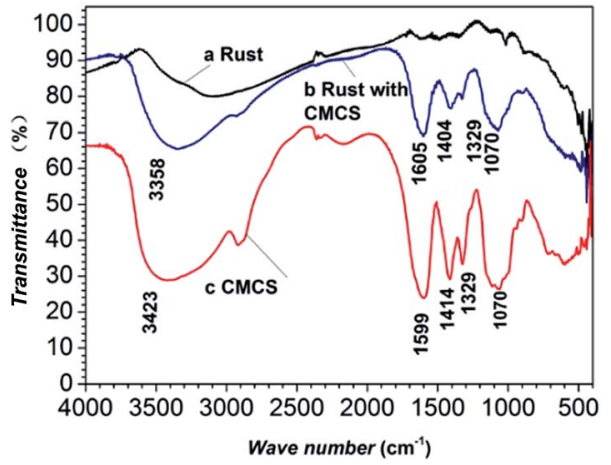

Fig. 5 FTIR spectra of CMCS and corrosion products after 5 days of immersion at $303 \mathrm{~K}$ in seawater with or without an inhibitor: (a) blank; (b) $0.25 \mathrm{~g} \mathrm{~L}^{-1}$ CMCS; (c) CMCS.
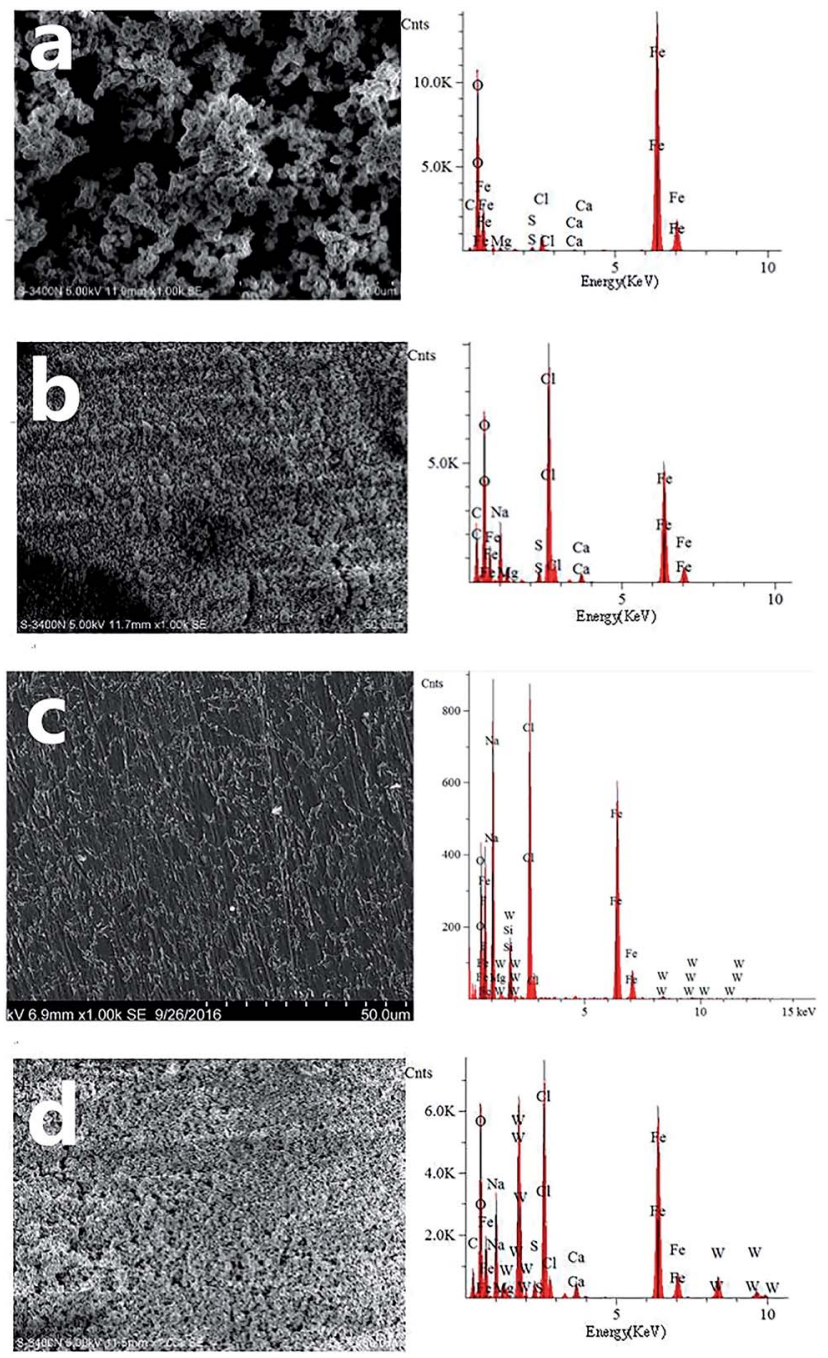

Fig. 6 SEM and EDS images of X70 after 5 days of immersion at $303 \mathrm{~K}$ in seawater in the absence (a) and the presence of $0.25 \mathrm{~g} \mathrm{~L}^{-1} \mathrm{CMCS}(\mathrm{b})$, $0.1 \mathrm{~g} \mathrm{~L}^{-1} \mathrm{Na}_{2} \mathrm{WO}_{4}$ (c) and $0.25 \mathrm{~g} \mathrm{~L}^{-1} \mathrm{CMCS}+0.1 \mathrm{~g} \mathrm{~L}^{-1} \mathrm{Na}_{2} \mathrm{WO}_{4}$ (d).

On the contrary, a dense surface structure is observed after immersion in seawater containing $0.25 \mathrm{~g} \mathrm{~L}^{-1}$ CMCS. This can also be seen in Fig. $6 \mathrm{c}$ for the samples immersed in the test solutions in the presence of $0.1 \mathrm{~g} \mathrm{~L}^{-1} \mathrm{Na}_{2} \mathrm{WO}_{4}$. The EDS pattern in Fig. $6 \mathrm{~b}$ shows that the corrosion product contained large amounts of $\mathrm{C}, \mathrm{O}, \mathrm{Fe}$ and very small amounts of $\mathrm{Mg}$ and $\mathrm{Ca}$.

Table 4 Chemical composition measured using EDS for X70 pipeline steel after 5 days of immersion in seawater in the absence and presence of the investigated inhibitors at $303 \mathrm{~K}$

\begin{tabular}{lclllll}
\hline $\begin{array}{l}\text { Inhibitor } \\
\text { concentration }\end{array}$ & $\begin{array}{l}\mathrm{C} \\
\mathrm{wt} \%\end{array}$ & $\begin{array}{l}\mathrm{O} \\
\mathrm{wt} \%\end{array}$ & $\begin{array}{l}\mathrm{Mg} \\
\mathrm{wt} \%\end{array}$ & $\begin{array}{l}\mathrm{Ca} \\
\mathrm{wt} \%\end{array}$ & $\begin{array}{l}\mathrm{Fe} \\
\mathrm{wt} \%\end{array}$ & $\begin{array}{l}\mathrm{W} \\
\mathrm{wt} \%\end{array}$ \\
\hline Blank solution & 2.1 & 33.6 & 0.8 & 0.2 & 63.4 & - \\
$0.25 \mathrm{~g} \mathrm{~L}^{-1} \mathrm{CMCS}^{-1}$ & 30.5 & 45.3 & 1.6 & 0.8 & 21.9 & - \\
$0.1 \mathrm{~g} \mathrm{~L}^{-1} \mathrm{Na}_{2} \mathrm{WO}_{4}$ & 23.9 & 20.9 & 0.9 & 0.7 & 27.6 & \\
$0.25 \mathrm{~g} \mathrm{~L}^{-1}$ & 14.0 & 36.8 & 1.2 & 1.3 & 29.0 & 17.7 \\
${\mathrm{CMCS}+0.1 \mathrm{~g} \mathrm{~L}^{-1}}$ & & & & & &
\end{tabular}

$\mathrm{CMCS}+0.1 \mathrm{~g} \mathrm{~L}^{-1}$

$\mathrm{Na}_{2} \mathrm{WO}_{4}$ 


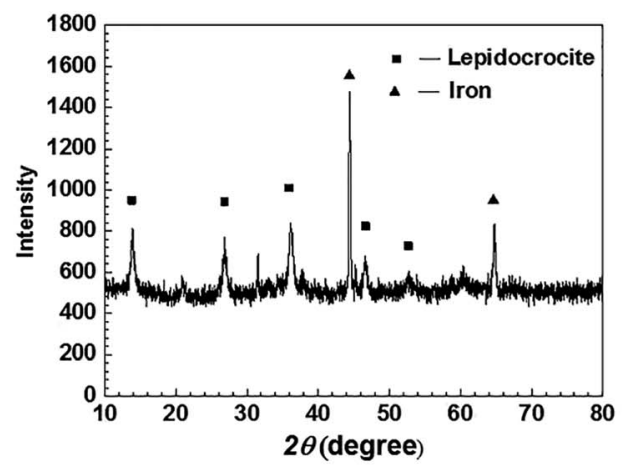

(a)

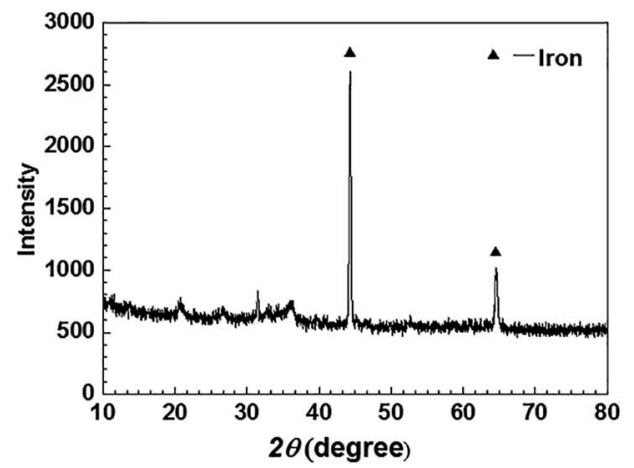

(b)

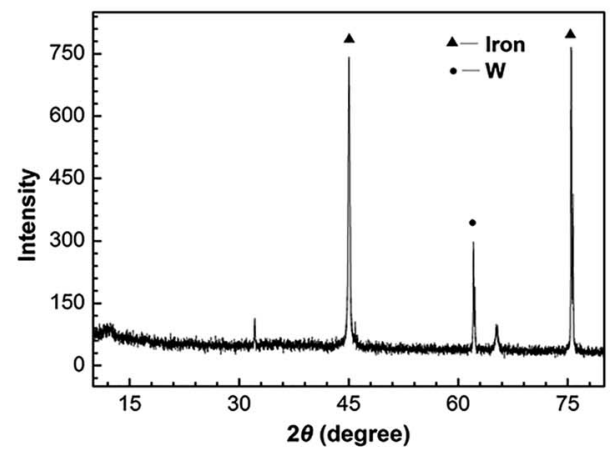

(c)

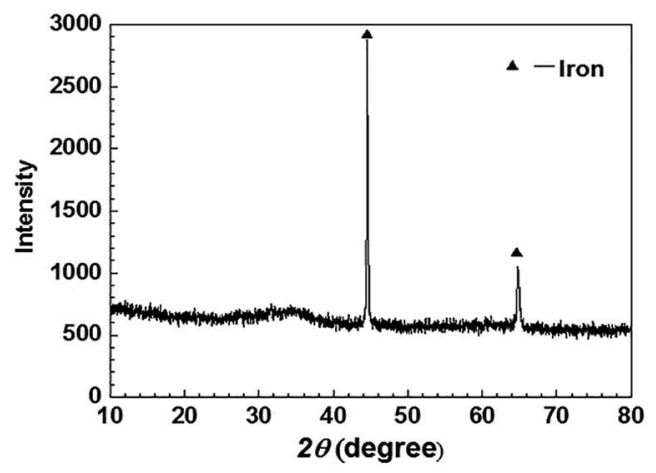

(d)

Fig. 7 XRD patterns of X70 after 5 days of immersion at $303 \mathrm{~K}$ in seawater in the absence (a) and the presence of $0.25 \mathrm{~g} \mathrm{~L}^{-1}$ CMCS (b), $0.1 \mathrm{~g} \mathrm{~L}^{-1} \mathrm{Na}_{2} \mathrm{WO}_{4}$ (c) and $0.25 \mathrm{~g} \mathrm{~L}^{-1} \mathrm{CMCS}+0.1 \mathrm{~g} \mathrm{~L}^{-1} \mathrm{Na}_{2} \mathrm{WO}_{4}$ (d).
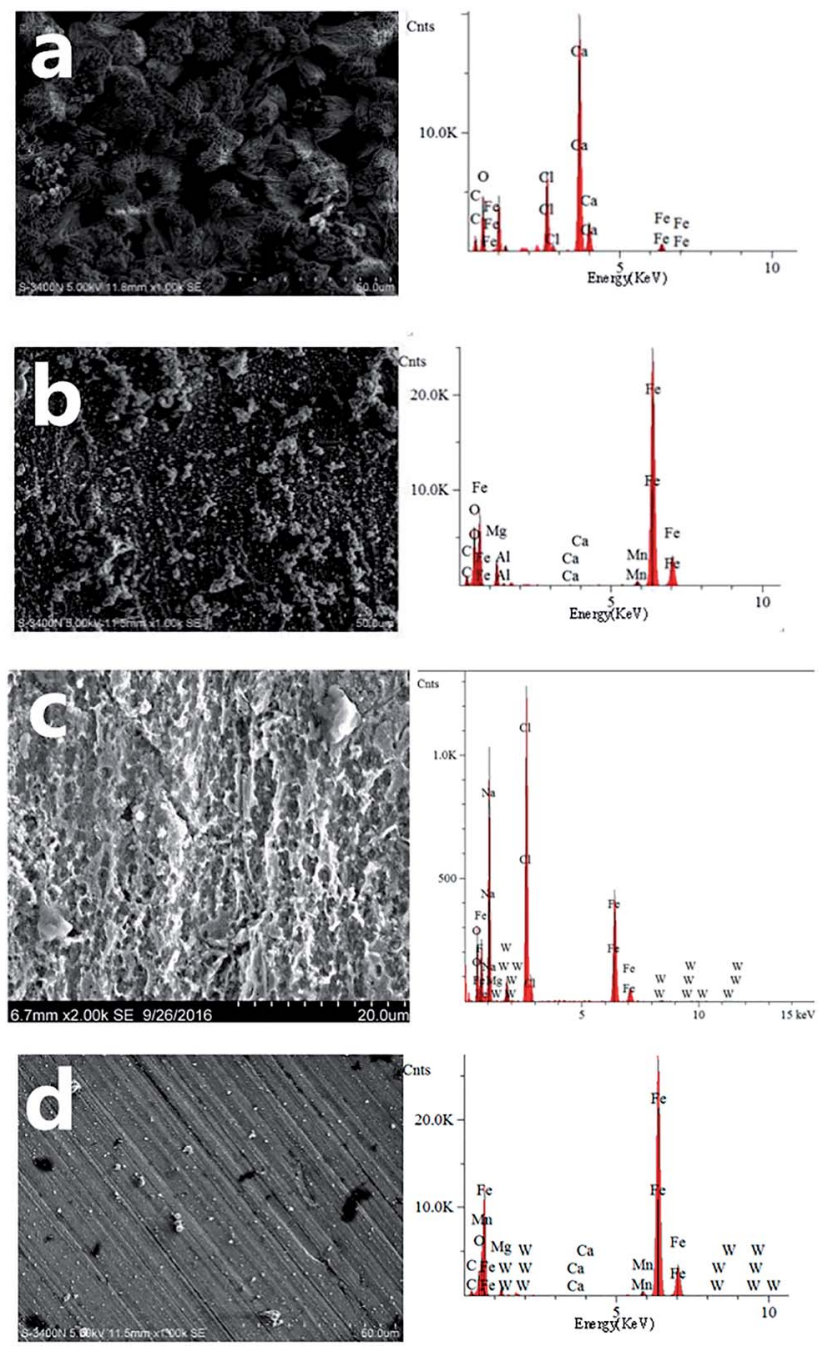

Fig. 8 SEM and EDS results of $X 70$ after 5 days of immersion at $303 \mathrm{~K}$ in seawater at $-0.85 \mathrm{~V}$ in the absence (a) and the presence of $0.25 \mathrm{~g}$ $\mathrm{L}^{-1} \mathrm{CMCS}$ (b), $0.1 \mathrm{~g} \mathrm{~L}^{-1} \mathrm{Na}_{2} \mathrm{WO}_{4}$ (c) and $0.25 \mathrm{~g} \mathrm{~L}^{-1} \mathrm{CMCS}+0.1 \mathrm{~g} \mathrm{~L}^{-1}$ $\mathrm{Na}_{2} \mathrm{WO}_{4}(\mathrm{~d})$.

There is no crystalline corrosion product because only iron was detected by XRD (Fig. 7b). According to the FTIR spectra, CMCS was detected in the product (see Fig. 5). These results illustrate that CMCS was absorbed on the metal surface and effectively reduced the corrosion rate. The surface is also dense when

Table 5 Chemical composition measured using EDS for X70 pipeline steel after 5 days of immersion at $303 \mathrm{~K}$ in seawater in the absence and presence of the investigated inhibitors at $-0.85 \mathrm{~V}$

\begin{tabular}{lrlllll}
\hline $\begin{array}{l}\text { Inhibitor } \\
\text { concentration }\end{array}$ & \multicolumn{1}{c}{$\begin{array}{l}\mathrm{O} \\
\mathrm{wt} \%\end{array}$} & $\begin{array}{l}\mathrm{Mg} \% \\
\mathrm{wt} \%\end{array}$ & $\begin{array}{l}\mathrm{Ca} \\
\mathrm{wt} \%\end{array}$ & $\begin{array}{l}\text { Fe } \\
\text { wt\% }\end{array}$ & $\begin{array}{l}\text { W } \\
\text { wt\% }\end{array}$ \\
\hline Blank solution & 12.0 & 46.5 & 1.2 & 37.3 & 3.0 & - \\
$0.25 \mathrm{~g} \mathrm{~L}^{-1} \mathrm{CMCS}^{-1}$ & 6.9 & 14.9 & 6.0 & 0.1 & 72.0 & - \\
$0.1 \mathrm{~g} \mathrm{~L}^{-1} \mathrm{Na}_{2} \mathrm{WO}_{4}$ & 5.6 & 8.9 & 3.4 & 0.1 & 78.6 & 1.5 \\
$0.25 \mathrm{~g} \mathrm{~L}^{-1}$ & 4.3 & 7.4 & 2.5 & 0.1 & 85.5 & 0.3
\end{tabular}

CMCS + $0.1 \mathrm{~g} \mathrm{~L}^{-1}$

$\mathrm{Na}_{2} \mathrm{WO}_{4}$ 


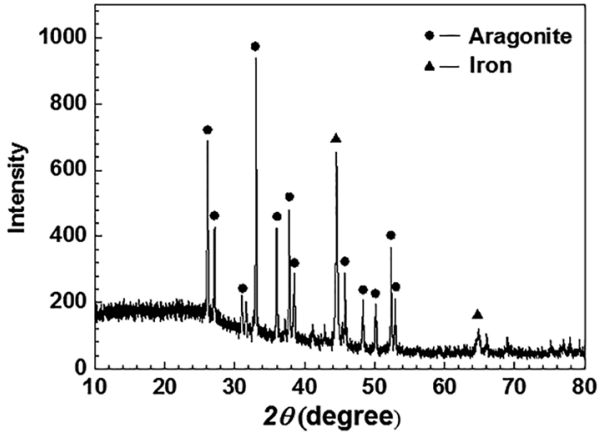

(a)

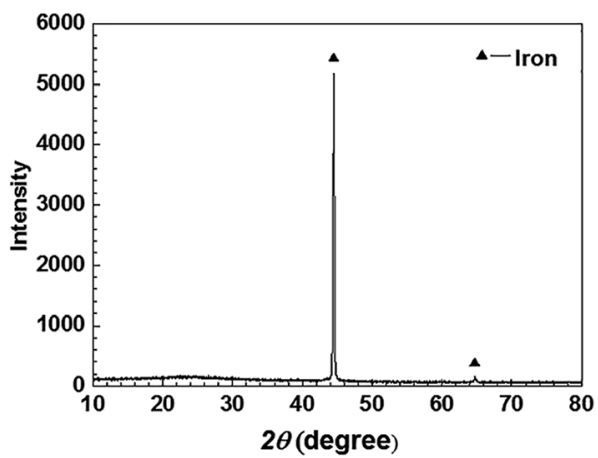

(b)

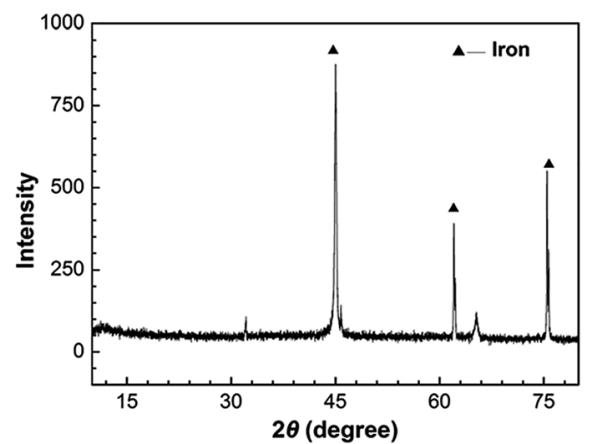

(c)

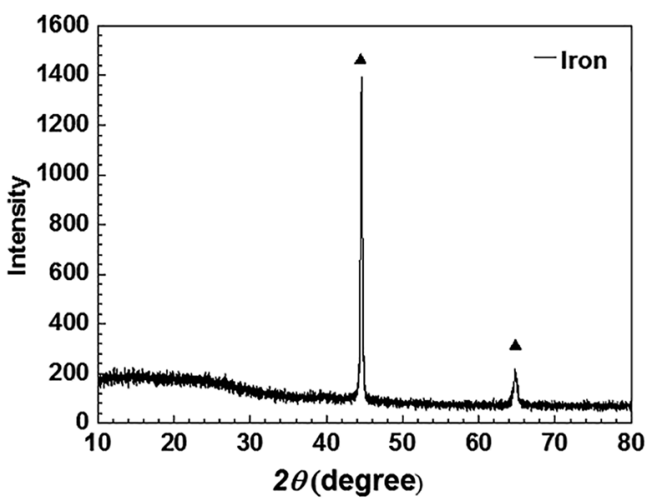

(d)

Fig. 9 XRD patterns of X70 after 5 days of immersion at $303 \mathrm{~K}$ in seawater at $-0.85 \mathrm{~V}$ in the absence (a) and the presence of $0.25 \mathrm{~g} \mathrm{~L}^{-1}$ CMCS (b), $0.1 \mathrm{~g} \mathrm{~L}^{-1} \mathrm{Na}_{2} \mathrm{WO}_{4}$ (c) and $0.25 \mathrm{~g} \mathrm{~L}^{-1} \mathrm{CMCS}+0.1 \mathrm{~g} \mathrm{~L}^{-1}$ $\mathrm{Na}_{2} \mathrm{WO}_{4}$ (d).

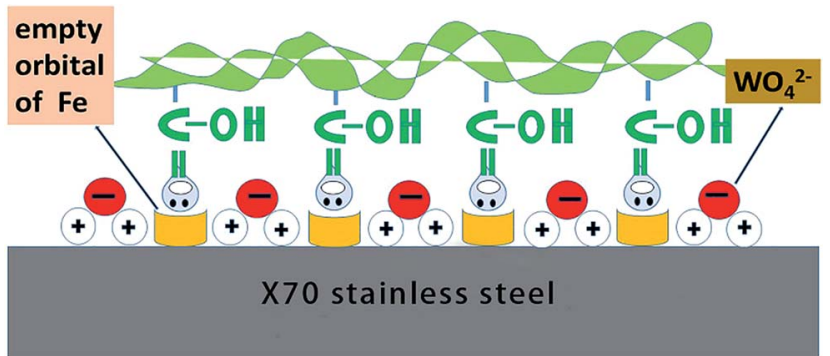

Fig. 10 Proposed adsorption model for the synergistic mechanism between CMCS and tungsten acid radical ions.

$0.25 \mathrm{~g} \mathrm{~L}^{-1} \mathrm{CMCS}$ and $0.1 \mathrm{~g} \mathrm{~L}^{-1} \mathrm{Na}_{2} \mathrm{WO}_{4}$ were added. Compared to the EDS pattern in Fig. 6b, a large amount of $\mathrm{W}$ was detected, and the XRD pattern (Fig. 7d) shows no iron oxides or hydroxides. CMCS and $\mathrm{Na}_{2} \mathrm{WO}_{4}$ served well as combined inhibitors for corrosion. This is consistent with the results of the EIS analysis.

Fig. 8 shows the SEM images and EDS obtained from the surface of the X70 pipeline steel after 5 days of immersion at 303 $\mathrm{K}$ in seawater at $-0.85 \mathrm{~V}$ in the absence (a) and the presence of $0.5 \mathrm{~g} \mathrm{~L}^{-1} \mathrm{CMCS}$ (b), $0.1 \mathrm{~g} \mathrm{~L}^{-1} \mathrm{Na}_{2} \mathrm{WO}_{4}$ (c) and $0.25 \mathrm{~g} \mathrm{~L}^{-1} \mathrm{CMCS}+$ $0.1 \mathrm{~g} \mathrm{~L}^{-1} \mathrm{Na}_{2} \mathrm{WO}_{4}$ (d). The calculation of the surface element content is shown in Table 5 . $\mathrm{Na}$ and $\mathrm{Cl}$ are not shown in Table 5. Particles are observed in Fig. 8a when a potential of $-0.85 \mathrm{~V}$ was applied on the samples in seawater, indicating the formation of a dense layer. The EDS pattern in Fig. 8a indicates that the main elements were $\mathrm{Ca}, \mathrm{C}$ and $\mathrm{O}$. This is consistent with the results of the XRD in Fig. 9, which indicates that the main component is $\mathrm{CaCO}_{3}$. The calcareous deposit may promote the formation of a physical barrier against oxygen and thus decrease the corrosion rate. ${ }^{30}$ However, in a circulating cooling water system, the calcareous deposit will thicken with time, and it may impede the circulation of water and hinder the dissipation of heat.

After the addition of $0.25 \mathrm{~g} \mathrm{~L}^{-1} \mathrm{CMCS}$, the Ca and Fe content is $0.1 \%$ and $72 \%$, respectively (Table 5 ). Compared to the EDS pattern in Fig. 8a, much fewer products are observed in the EDS pattern in Fig. 8b. After the addition of $0.25 \mathrm{~g} \mathrm{~L}^{-1}$ CMCS and $0.1 \mathrm{~g} \mathrm{~L}^{-1} \mathrm{Na}_{2} \mathrm{WO}_{4}$, the morphology of the sample surface was smooth without any sign of corrosion, as seen in the SEM image in Fig. 8c, and the content of Fe on the surface reached $85.5 \%$ (Table 5). The XRD pattern obtained from the metal surface after immersion in seawater (Fig. 9d) shows that the main component is Fe. This indicates that the addition of CMCS could effectively restrain the deposition progress of calcareous products under cathodic protection at $-0.85 \mathrm{~V}$.

Compared to samples in seawater without inhibitors, the addition of $0.25 \mathrm{~g} \mathrm{~L}^{-1} \mathrm{CMCS}$ and $0.1 \mathrm{~g} \mathrm{~L}^{-1} \mathrm{Na}_{2} \mathrm{WO}_{4}$ decreased the corrosion rate by $85.7 \%$. This study shows that the combination of inhibitors and cathodic protection effectively retard the corrosion of X70 pipeline steel.

The adsorption mechanism to explain the synergistic inhibitory effect of CMCS and $\mathrm{Na}_{2} \mathrm{WO}_{4}$ is shown in Fig. 10 . CMCS contains a large amount of carboxyl groups, which can form coordination bonds with $3 \mathrm{~d}$ empty orbitals of $\mathrm{Fe}$ on the surface of the substrate material. When $\mathrm{Na}_{2} \mathrm{WO}_{4}$ is added into the solution, it is hydrolyzed to form tungsten acid radical ions. 
Because the electrode surface has extra positive charges in the blank solution, $\mathrm{WO}_{4}{ }^{2-}$ adsorbs on the metal surface due to the coulombic force. Thus, the synergistic protective effect of CMCS and $\mathrm{Na}_{2} \mathrm{WO}_{4}$ causes the inhibition film to become more compact and thicker, resulting in an increase of $R_{\mathrm{ct}}$ and a decrease of $C_{\mathrm{dl}}$.

\section{Conclusions}

In this study, we showed that CMCS can inhibit the corrosion of X70 in seawater. The corrosion efficiency reached $80.95 \%$ at a concentration of $0.25 \mathrm{~g} \mathrm{~L}^{-1}$. As corrosion inhibitors, CMCS and $\mathrm{Na}_{2} \mathrm{WO}_{4}$ show an excellent synergy for the protection of X70 pipeline steel in seawater. Following the addition of $0.25 \mathrm{~g} \mathrm{~L}^{-1}$ CMCS and $0.1 \mathrm{~g} \mathrm{~L}^{-1} \mathrm{Na}_{2} \mathrm{WO}_{4}$, the inhibition efficiency reached $90.04 \%$. Finally, the combination of corrosion inhibitors and cathodic protection shows a good synergistic effect on the protection of X70 pipeline steel. While a calcareous deposit forms on the metal surface in blank seawater, it cannot form in the presence of CMCS and $\mathrm{Na}_{2} \mathrm{WO}_{4}$, and there was no sign of corrosion.

\section{Acknowledgements}

This paper is supported by National Natural Science Foundation of China (No. 41276074) and local fund (No. 13-1-4-122jch).

\section{References}

1 M. R. Choudhury, M.-K. Hsieh, R. D. Vidic and D. A. Dzombak, Corrosion management in power plant cooling systems using tertiary-treated municipal wastewater as makeup water, Corros. Sci., 2012, 61, 231-241.

2 C. Gao, Accelerate the development of seawater utilization technology industry and policy, J. Ocean Univ. China, 2004, 03, 5-8.

3 L. Zeng, The corrosion mechanism and protection of CS pipe of cooling water system in coastal power plant, Huadian Technol., 2009, 11, 32-33, 41, 82.

4 R. A. J. L. L. Sheir, Corrosion, Butterworth-Heinmann Ltd, Great Britain, 1994.

5 S. N. Banerjee, An Introduction to Science of Corrosion and its Inhibition, Oxonian Press PVT Ltd, India, 1985.

6 I. L. Rozenfeld, Corrosion Inhibition, McGraw-Hill Inc, USA, 1981.

7 D. A. Jones, Principles and Prevention of Corrosion, Macmillan Publishing Company, USA, 1991.

$8 \mathrm{H}$. Brinis and M. E. Samar, A method for inhibiting scale formation and corrosion in a cooling water system, Desalin. Water Treat., 2014, 52(13-15), 2609-2619.

9 K. T. C. W. David, Method of inhibiting scale and corrosion in aqueous systems using low molecular weight polymers, US, 02.11, 1995.06.06, 1997.

$10 \mathrm{Z}$. Amjad, Effect of surfactants on gypsum scale inhibition by polymeric inhibitors, Desalination, 2011, 36(1-3), 270-279.
11 G. E. Geiger, Improve corrosion and deposition control in alkaline cooling, Hydrocarbon Process., 1996, 75(1), 93-98.

12 M. N. V. Ravi Kumar, A review of chitin and chitosan applications, React. Funct. Polym., 2000, 46(1), 1-27.

13 R. P. Carlson, R. Taffs, W. M. Davison and P. S. Stewart, Antibiofilm properties of chitosan-coated surfaces, J. Biomater. Sci., Polym. Ed., 2008, 19(8), 1035-1046.

14 A. M. Elbarbary and T. B. Mostafa, Effect of gamma-rays on carboxymethyl chitosan for use as antioxidant and preservative coating for peach fruit, Carbohydr. Polym., 2014, 104, 109-117.

15 I. Gurrappa, Cathodic protection of cooling water systems and selection of appropriate materials, J. Mater. Process. Technol., 2005, 166(2), 256-267.

16 L. L. Shreir, Design and Operational Guidance on Cathodic Protection of Offshore Structures, The Marine Technology Directorate Limited Publication, London, 1990.

$17 \mathrm{~J}$. C. Lin and H. C. Shih, The dual character of an aluminium-thiourea mixture in an $\mathrm{NaCl}$ aqueous solution-an inhibitor and an accelerator of corrosion for low carbon steel, Corros. Sci., 1987, 27(8), 839-858.

18 H. C. S. J. C. Lin, Improvement of the Current Efficiency of an AI-Zn-ln Anode by Heat-Treatment, J. Electrochem. Soc., 1987, 134(4), 817-823.

19 J.-C. Lin, S.-L. Chang and S.-L. Lee, Corrosion inhibition of steel by thiourea and cations under incomplete cathodic protection in a $3.5 \% \mathrm{NaCl}$ solution and seawater, J. Appl. Electrochem., 1999, (8), 911-918.

20 Y. Zhao, J. Wu, H. Yu, J. Wang, G. Liu and J. Qian, Synthetic Protection Effect of Inhibitor and Cathodic Protection on Ship Building Steel, Mater. Prot., 2002, 35(4), 41-43.

21 S. Sharma, K. H. Parikh and M. Neog, Cathodic protection of tin-Coated steel in monochloroacetic acid $\left(0.5 \mathrm{~mol} \mathrm{dm}^{(-3)}\right)$ in presence of chromates and dichromates, J. Indian Chem. Soc., 2011, 88(4), 603-606.

22 W. Wang, S. Liu, Z. Cui, X. Hou, J. Wang, L. Gao, X. Gao, Z. Zhang, J. Wu and C. Hou, Discussion on the joint application technique of corrosion inhibitor and cathodic protection to seawater cooling systems, Ind. Water Treat., 2013, 33(5), 1-3.

23 C. C. Pierce, C. Sui and G. E. Geiger, Cooling Treatment Performance Optimization Under Alkaline Stressed Conditions, NACE International, 2010.

24 R. D. Letterman, Water Quality and Treatment: A Handbook of Community Water Supplies, McGraw-Hill, New York, 1999.

$25 \mathrm{H}$. Brinis and M. E. H. Samar, A method of making an aqueous dispersion of polyaniline and inhibiting corrosion in cooling water, Desalin. Water Treat., 2012, 44(1-3), 190196.

26 N. D. Nam, A. Somers, M. Mathesh, M. Seter, B. Hinton, M. Forsyth and M. Y. J. Tan, The behaviour of praseodymium 4-hydroxycinnamate as an inhibitor for carbon dioxide corrosion and oxygen corrosion of steel in $\mathrm{NaCl}$ solutions, Corros. Sci., 2014, 80, 128-138.

27 E. A. Noor, Evaluation of inhibitive action of some quaternary N-heterocyclic compounds on the corrosion of 
$\mathrm{Al}-\mathrm{Cu}$ alloy in hydrochloric acid, Mater. Chem. Phys., 2009, 114, 533-541.

28 H. Fan, S. Li, Z. Zhao, H. Wang, Z. Shi and L. Zhang, Inhibition of brass corrosion in sodium chloride solutions by self-assembled silane films, Corros. Sci., 2011, 53, 42734281.

29 J. Zhao and G. Chen, The synergistic inhibition effect of oleic-based imidazoline and sodium benzoate on mild steel corrosion in a $\mathrm{CO}_{2}$-saturated brine solution, Electrochim. Acta, 2012, 69, 247-255.

30 N. A. Mohamed and N. A. Abd El-Ghany, Preparation and antimicrobial activity of some carboxymethyl chitosan acyl thiourea derivatives, Int. J. Biol. Macromol., 2012, 50(5), 1280-1285.
31 J. Lv, Q. Zhou, G. Liu, D. Gao and C. Wang, Preparation and properties of polyester fabrics grafted with $O$-carboxymethyl chitosan, Carbohydr. Polym., 2014, 113, 344-352.

32 T. Baran, A. Mentes and H. Arslan, Synthesis and characterization of water soluble $O$-carboxymethyl chitosan Schiff bases and Cu(II) complexes, Int. J. Biol. Macromol., 2015, 72, 94-103.

33 C. Barchiche, C. Deslouis, D. Festy, O. Gil, P. Refait, S. Touzain and B. Tribollet, Characterization of calcareous deposits in artificial seawater by impedance techniques 3deposit of $\mathrm{CaCO}_{3}$ in the presence of $\mathrm{Mg}(\mathrm{II})$, Electrochim. Acta, 2003, 48(12), 1645-1654. 